DOI: https://doi.org/10.47405/mjssh.v6i10.1044

\begin{tabular}{|c|c|}
\hline 4 & Malaysian Journal of Social Sciences and Humanities (MJSSH) \\
\hline $\begin{array}{l}\text { Malaysian Juoural of } \\
\text { Social ccciecces and }\end{array}$ & Volume 6, Issue 10, October 2021 \\
\hline (MJ-sSH) & e-ISSN : 2504-8562 \\
\hline & $\begin{array}{l}\text { Journal home page: } \\
\text { www.msocialsciences.com }\end{array}$ \\
\hline
\end{tabular}

\title{
Rights of Redress on Supply of Goods under Consumer Protection Act 1999: The Issue of Halal Logo
}

\author{
Nasihah Naimat ${ }^{1}$, Elistina Abu Bakar ${ }^{2}$ \\ 1Faculty of Law, Universiti Teknologi MARA, Melaka, Malaysia \\ 2Department of Resource Management and Consumer Studies, Faculty of Ecology, \\ Universiti Putra Malaysia (UPM), Malaysia
}

Correspondence: Nasihah Naimat (nasihahnaimat@uitm.edu.my)

\begin{abstract}
Halal logo is designed to protect consumers from fraud and mislabelling. However, over the years, there has been a controversy surrounding the use of a false halal logo to attract Muslim consumers to buy certain goods. The act of unethical business practice to attract consumers to buy their goods have caused some misunderstanding among consumers regarding the halal status of such goods. Therefore, the law is the most important mechanism in protecting the rights and interests of consumers to claim compensation if their rights have been violated. Under the Consumer Protection Act (CPA) 1999, it puts a responsibility on suppliers and manufacturers to ensure that the goods supplied are the same as specified. However, the question arises as to the extent to which consumers have the right of redress under the CPA 1999 in the issue of supplying false halal logo goods. By using the content analysis method, this article aims to analyze the scope and provisions of the CPA 1999 that govern matters relating to the supply of goods. The discussion of this article reveals that Part VI and VII of the CPA 1999 contains several loopholes that must be addressed in order to provide better rights of redress to consumers on the issue of supplying false halal logo goods.
\end{abstract}

Keywords: redress, consumer, suppliers, manufacturers, halal

\section{Introduction}

The dynamics driving forces of the halal industry worldwide have an impact on the halal industry in Malaysia. However, despite the development of the halal industry in Malaysia, consumers are still exposed to abuses involving halal goods. We have seen some of the local product brands have come out to the public as "Islamic" brands such as the use of Arabic language or Jawi writing on the packaging and labelling. This can be considered as one of their marketing strategies to attract Muslim consumers to buy the goods. These unethical acts or representations made by suppliers and manufacturers to attract consumers to buy their goods and at the same time have caused some misunderstanding among consumers regarding the halal status of such goods (Ahmad, Mohd Noor \& Fitri, 2014; Halim \& Ahmad, 2014). Consumers believe that using the halal logo is compulsory, but in reality, it is not (Halim \& Ahmad, 2014). However, if the goods is marked as halal, then the suppliers or manufacturers of the goods is responsible for ensuring that the goods is halal as stated under the Trade Descriptions Act (TDA) 2011. 
In Malaysia, the main legislation regulating halal issues are the Trade Descriptions Act (TDA) 2011 and two Orders, namely, the Trade Descriptions (Definition of Halal) Order 2011 and the Trade Descriptions (Certification and Marking of Halal) Order 2011. However, the Act as well as the Orders are criminal in nature, which is used as a tool to punish offenders and does not provide compensation for victims of false halal logo and non-halal goods (Amin \& Aziz, 2015). Furthermore, TDA 2011 was enacted to regulate trade by prohibiting the use of false trade descriptions rather than to compensate consumers. If consumers have an opportunity to take action and file claims against suppliers and manufacturers of false halal logo goods, then suppliers and manufacturers will not take lightly the responsibility of ensuring that the halal logo on their goods is recognized by the Department of Islamic Development Malaysia (JAKIM). This could indirectly prevent suppliers and manufacturers from engaging in unethical business in the future. As such, there is a need to review the Consumer Protection Act 1999 which gives consumers the right to claim compensation.

The Consumer Protection Act (CPA) 1999 came into force on 15 November 1999 to strengthen the protection of consumers. The CPA 1999 is important in ensuring that consumers' rights are protected and that any problems can be resolved, especially transactions involving consumers. Consumers are often in a detrimental position and lack of the ability to protect themselves from dishonesty or exploitation by suppliers and manufacturers. Therefore, liability should be placed on suppliers and manufacturers for the purpose of protecting consumers. Because the objective of the CPA 1999 is to protect consumers, some important provisions contained in the CPA 1999 are seen to be more beneficial in protecting the interest of consumers. The CPA 1999 provides for implied guarantees that must be complied with by suppliers and manufacturers in the supply of goods. Breach of an implied guarantee by the suppliers or manufacturers gives the consumer the right to claim compensation. Thus, using the content analysis method, this article discusses the extent to which the CPA 1999 provides sufficient redress to compensate consumers in respect of the supply of false halal logo and non-halal goods. It first provides a brief discussion on the implied guarantees in a contract of supply of goods under Part V of the CPA 1999 and the remainder of the article is devoted to the discussion on the right of redress under Part VI and Part VII of the CPA 1999.

\section{Guarantees in respect of supply of goods}

Part V of the CPA 1999 provides for the implied guarantees that must be complied with by the suppliers and manufacturers in the case of the supply of goods. Breach of the implied guarantee by the suppliers gives the consumer the right to damages. Part V was introduced with the aim of protecting consumers when entering into contracts for the supply of goods. This is to ensure that consumers obtain the goods as they have been paid for. Before any claim is made under Parts VI and VII of APP 1999, the consumer must prove that the suppliers or manufacturers has breached one of the implied guarantees under Part V of the CPA 1999. The CPA 1999 provides seven implied guarantees in respect to the supply of goods to consumers. Out of seven implied guarantees stated in the CPA 1999, only two are related to the issue of halal: the implied guarantee as to acceptable quality (section 32) and the implied guarantee that goods comply with description (section 34). However, this article does not comprehensively discuss the implied guarantees as the main purpose is to discuss in relation to the rights granted to consumers in breach of the implied guarantees in the supply of goods.

Section 32 of the CPA 1999 introduces a standard of quality in the supply of goods. Section 32(2)(a) of the CPA 1999 provides that acceptable quality goods refer to goods that are suitable for the actual purpose, free from minor defects, acceptable in terms of appearance and finish, safe and durable. Section 32 (2)(b) of the CPA 1999 provides that these acceptable quality criteria must be balanced with the consumer's expectations about the nature of the goods, the price, any statements made about the goods on any packaging or label, and any representation made about the goods by the suppliers or manufacturers. The overall assessment of the goods, as well as consumer knowledge and expectations of them, is used to determine whether the goods are of acceptable quality (Amin, 2008). Nevertheless, on the issue of halal, the consumer can expect that the goods are halal based on any statement or label displayed on the package. Hence, a false halal logo arguably does not correspond to the quality as it does not meet the criteria for the acceptable quality of halal goods (Amin \& Aziz, 2015). 
Section 34 of the CPA 1999 provides that in the supply of goods, there shall be an implied guarantee that the goods are equivalent to the description. If the goods purchased by the consumer do not comply with the description, then the suppliers is deemed to have breached the implied guarantees under this section. The term "description" can refer to any expression or act that describes the goods to be sold (Abu Bakar, 2013). In other words, "description" refers to a description of a goods based on its characteristics or quality. The halal logo should be regarded as an important aspect of the goods description because it generally refers to words that indicate the type of goods supplied (Amin \& Aziz, 2015). Muslim consumers have the right to expect that the goods is halal if it demonstrates any halal expression or act indicating that the goods is halal as described on the labelling and packaging information. It is considered a breach of a contractual term if the sale of a non-halal goods was claimed to be halal either through labeling, representation or by any other means (A Rahman, Ismail, \& Abdullah, 2018).

\section{Right of Redress under Part VI and its problems}

In Part VI of the CPA 1999 provides rights against suppliers in respect of guarantees in the supply of goods. Section 39 of the CPA 1999 gives a consumer a right of redress against the suppliers of goods where the goods fail to comply with any of the implied guarantees under sections 31 to 37 (Part V). Under Part VI there are two important issues that need to be discussed, namely the issue of suppliers avoids liability and the issue of remedies.

The first issue is that the suppliers avoid liability. In general, section 42 (1) of the CPA 1999 provides four types of remedies: repairing the goods, curing any defect in title, replacing the goods, and refunding any money paid or other consideration to the consumer. Section 40 provided that "there shall be no right of redress against the supplier of goods under this Act in respect of the failure of the goods to comply with the implied guarantee as to acceptable quality where:

(a) the manufacturer makes a representation in respect of the goods otherwise than by a statement on any packaging or label; and

(b) the goods would have complied with the implied guarantee as to acceptable quality if that representation had not been made".

Clearly, these exceptions do not meet the main objective of consumer protection which should provide consumers with appropriate redress (Zakuan, \& Ahmad Yusoff, 2011). This provision excludes the suppliers from any liability when the manufacturers make a representation on behalf of the suppliers. In which, the consumer would have no rights of redress against the suppliers. On the issue of halal, the suppliers will not be liable if the manufacturers falsely represents that the goods is halal when it is not.

In addition, section 48(2) of the CPA 1999 also provides that suppliers can avoid liability. Section 48(2) provides that:
"Without prejudice to any other rights or remedies to which a supplier may be entitled, a supplier shall be entitled, where the representation was made without his express or implied authority, to be indemnified by the dealer who made the representation and by any person on whose behalf the dealer was acting in making it, against any damage suffered by the supplier through the operation of subsection (1)".

The above provision states that the suppliers shall not be liable if the dealer or any person acting as the dealer makes any express or implied representation to the consumer. This will make the consumer has no right of redress against the suppliers if a representation is made by a dealer or any person acting as a dealer. The suppliers should be responsible for the representations made by the dealer or any person acting on behalf of the dealer even if they have delivered the goods to the dealer. This is due to the fact that the goods are the products of the suppliers and that the suppliers should be responsible from before, during and after the marketing of the goods. The existence of section 40 and 48 (2) of the CPA 
1999 is clearly contrary to the main objective of the CPA 1999 which is to protect consumers. It is suggested that exceptions under section 40 and 48 (2) of the CPA 1999 be abolished.

In contrast to the provision under section 16 (1) of the TDA 2011, which provides that "No person shall make any false representation by any means, whether direct or indirect, that any goods or services supplied by him or any methods adopted by him are of a kind supplied to or approved by any person including any government or government department or agency or any international body or agency whether in Malaysia or abroad". Briefly, this section states that everyone involved in the supply chain is responsible for any representations. It is a good provision but it does not entitle the consumer to claim compensation as the TDA 2011 is criminal in nature.

The second issue is the question of remedies. Section 41 (1) of the CPA 1999 provides remedies to the consumer if the goods supplied by the supplier do not comply with the guarantee under Part V of the CPA 1999. Section 41(1)(a) of the CPA 1999 provides that where the failure is one that can be remedied, the consumer may require the supplier to remedy a defect within a reasonable time. By looking at the provision under section 41 (1) (a) of the CPA 1999 it limits consumer claims to simply requiring the suppliers to remedy a defect (Yusoff, 2008). Section 41 (1) (a) of the CPA 1999 seems to suggest that the remedial choice is of the suppliers rather than the consumer's choice. It is because only the suppliers can determine whether the failure is a failure that can or cannot be remedied (Chin \& Yusoff, 2017). This is seen as unfair to the consumer as the consumer does not have the right to reject the goods. The consumer should have the right to reject the goods and claim damages if the suppliers fails in any of the implied guarantee, even if such failure can be remedied. Further there is no definition of what is meant by a failure that can be remedied. It might be difficult to determine the extent to which a failure can be remedied in some situations (Chin \& Yusoff, 2017).

Meanwhile, section 41 (1) (b) of the CPA 1999 provides that where a failure is one that cannot be remedied or is one of substantial character, the consumer can cancel the contract or obtain from the supplier damages in compensation for any reduction in the value of the goods resulting from the goods below the price paid or payable by the consumer for the goods. This provision is seen to benefit the consumer as the consumer can reject the goods without having to prove whether the breach is a breach of condition or warranty which has been proven difficult to prove under the law of contract (Reynolds, 1963). The CPA 1999 makes the burden of proof easier on the part of the consumer because the only thing that must be determined is whether or not the breach can be remedied. If the goods "can" be repaired, then it is not substantial. A false halal logo or non-halal goods can be considered a substantial failure and entitle a consumer to reject or obtain damages in compensation. This is due to the fact that the goods will not be able to be repaired.

However, if the consumer exercises the right to reject the goods, the consumer only has the option of obtaining a refund or replacement of the goods. This is provided under section 46 (1) of the CPA 1999: "Where the consumer exercises the right to reject goods conferred under this Act, the consumer may choose to have:

(a) a refund of any money paid or other consideration provided by the consumer in respect of the rejected goods; or

(b) goods of the same type and of similar value to replace the rejected goods where such goods are reasonably available to the supplier as part of the stock of the supplier, and the supplier shall make provision accordingly".

Section 46 (1) of the CPA 1999 creates injustice to consumers in halal issues because if Muslim consumers buy false halal logo goods, they only get a refund of any money or a replacement of the goods. The fact is, what Muslim consumers have suffered is more than the value of the money that has been paid for the goods because not all damages can be assessed through money. Compared with the Australian Competition and Consumer Act 2010 and United Kingdom Consumer Rights Act 2015 which give more rights to consumers in the case of rejection of goods. Section 263 (4) of the Australian Competition and Consumer Act 2010 provides that: "The supplier must, in accordance with an election made by the consumer:

(a) refund: 
(i) any money paid by the consumer for the goods; and

(ii) an amount that is equal to the value of any other consideration provided by the consumer for the goods; or

(b) replace the rejected goods with goods of the same type, and of similar value, if such goods are reasonably available to the supplier".

Whereas, section 19(11) of the United Kingdom Consumer Rights Act 2015 provides that: "Those other remedies include any of the following that is open to the consumer in the circumstances-

(a) claiming damages;

(b) seeking specific performance;

(c) seeking an order for specific implement;

(d) relying on the breach against a claim by the trader for the price;

(e) for breach of an express term, exercising a right to treat the contract as at an end".

Thus, it is suggested that a similar provision be included under the CPA 1999 to provide better rights to consumers.

\section{Right of redress under Part VII and its problems}

Part VII of the CPA 1999 provides rights against manufacturers in respect of guarantees in the supply of goods. Section 50 of the CPA 1999 provides right of redress against manufacturers if the goods fail to comply with the guarantees under sections $32,34,37$ and 38 . The existence of this provision benefits the consumer when the consumer is given the right of redress against the manufacturers. However, under Part VII there is a problem of its own which is in relation to the manufacturers avoid liability. Under section 51 of the CPA 1999 which states that: "there shall be no right of redress against the manufacturer under this Act in respect of goods which fail to comply with the implied guarantee under section 32 or 34 where the failure is due to:

(a) an act, default or omission of, or any representation made by, a person other than the manufacturer; or

(b) a cause independent of human control, occurring after the goods have left the control of the manufacturer".

These exceptions provided by the CPA 1999 are clearly a shortcoming in a law that is supposed to protect consumers. These exceptions are seen as protecting the manufacturers rather than providing the right of redress to the consumers. In fact, these exceptions are unfair to the consumers because there is room for the manufacturer to avoid liability. This happens when a non-manufacturer, such as the supplier or importer acting on behalf of a manufacturer, commits an act, defaults or omissions, or makes any representation that causes injury or loss to a consumer, then the consumer has no right of redress against the manufacturers. In the context of halal, if a consumer purchases a goods based on a representation stating that the goods is halal, and this representation is made by a representative of the manufacturer, i.e., the supplier, then the consumers has no right of redress against the manufacturers.

Often, the manufacturers frequently requires the services of a third-party representative to promote their goods; in this case, the suppliers will act as the manufacturer's representative in order to advertise the goods. The advertising made by these suppliers will attract consumers to buy the goods manufactured by the manufacturer. The manufacturer should therefore be held liable for any acts or representations made by the supplier acting as a representative on behalf of the manufacturer in the event that the consumer suffers loss or injury after the use of the goods. Compared with section 16(1) of the TDA 2011 which provides that all those involved in the supply chain are liable for any false representations.

The exceptions under section 51 of the CPA 1999 seem to be in favor of the manufacturers. Manufacturers who are financially capable should bear the loss as compared to consumers (Adams \& Brownsword, 1987). Thus, exceptions under section 51 of the CPA 1999 be repealed (Zakuan, \& 
Yusoff, 2013) or otherwise, further expand the scope of the manufacturer's liability to include acts or representations made by the supplier or importer acting as a representative on behalf of the manufacturer (Zakuan \& Yusoff, 2011).

\section{Conclusion}

In ensuring that consumer rights are sufficiently protected, it should start with remedies. Remedy is a tool that is seen to be able to enforce consumer rights accordingly. Therefore, consumer protection laws should act as a protector for consumers in the event of a breach of the contract of sale. In the issue of halal, the failure of consumer protection laws to protect consumers can be seen in terms of the right of consumers to claim compensation. The discussion above reveals that there are several loopholes in Part VI and VII of the CPA 1999 that need to be remedied for better protection of consumers. The CPA 1999 is seen as incapable of addressing halal issues when it fails to provide appropriate remedies to consumers in respect of breach of implied guarantee by suppliers and manufacturers. As a fast-growing country in the halal industry, Malaysia should not be left behind in a matters of halal issues, especially in protecting consumers. Therefore, the CPA 1999 needs to be amended to grow in line with the development of the halal industry as well as to provide better protection for consumers.

\section{References}

A Rahman, A., Ismail, C. T., \& Abdullah, N. A. (2018). Regulating halal food consumption: Malaysian scenario. International Journal of Law, Government and Communication, 3(13), 313-321.

Abu Bakar, E. (2013). Undang-undang pengguna dalam konteks halalan toyyiban di Malaysia. In Deuraseh. N., Abdul Rahman. R., Mustafa. S., Bakar. J., \& Mat Hashim. D (Eds.), Halalan thoyyiban perspektif Malaysia (pp. 87-98). Institut Penyelidikan Produk Halal, Universiti Putra Malaysia.

Adams, J. N., \& Brownsword, R. (1987). The ideologies of contract. Legal Studies, 7(2), 205-223.

Ahmad, S., Mohd Noor, M.A., \& Fitri, L. (2014). Ketekalan gelagat pengguna Muslim terhadap status halal: Ke arah strategi berkesan promosi produk halal. Jurnal Pengguna Malaysia, 22, 51-68.

Amin, N. (2008) The consumer expectation test under the Consumer Protection Act 1999: A viable test for determining the quality and safety of products? The Law Review, 3, 367-385.

Amin, N., \& Aziz, N. A. (2015). The liability of the producer of false halal products under product liability law. Asian Social Science, 11(15), 295.

Chin, O. T., \& Yusoff, S. S. A. (2017). ASEAN Consumer Contract Laws: Consumer remedies in Malaysia and Singapore. International Business Management, 100(6), 1328-1335.

Halim, M. A. A., \& Ahmad, A. A. (2014). Enforcement of consumer protection laws on halal products: Malaysian experience. Asian Social Science, 10(3), 9-14.

Reynolds, F. M. B. Warranty, condition and fundamental term' (1963). Law Quarterly Review, 79, 534-555.

Yusoff, S. S. A. (2008). Perlindungan pengguna di bawah undang-undang: Pembekalan barang \& perkhidmatan. Jurnal Undang-undang dan Masyarakat, 12, 48-73.

Zakuan, Z. Z. M., \& Yusoff, S. S. A. (2011). Undang-undang pembekalan barang: Liabiliti pengilang terhadap barang cacat. Malaysian Journal of Consumer and Family Economics, 14, 113-130.

Zakuan, Z. Z. M., \& Yusoff, S. S. A. (2013). Liability of manufacturer for goods under the Consumer Protection Act 1999: A paradigm shift. Journal of Law, Policy and Globalization, 11, 31. 